\title{
A Novel Ratiometric Fluorescent Probe for Mercury (II) ions and Application in Bio-imaging
}

\author{
Qianmiao Gao ${ }^{1}$, Yang Jiao ${ }^{1,2, *}$, Cheng $\mathrm{He}^{1}$ and Chunying Duan ${ }^{1}$ \\ 1 State Key Laboratory of Fine Chemicals, Dalian University of Technology, Dalian 116024, China; \\ gaoqianmiao@outlook.com (Q.G); hecheng@dlut.edu.cn (C.H.); cyduan@dlut.edu.cn (C.D.) \\ 2 School of Chemical Engineering, Dalian University of Technology, Dalian 116024, China \\ * Correspondence: jiaoyang@dlut.edu.cn; Tel.: + 86-0411-84986296
}

Academic Editors: Run Zhang, D. Amilan Jose, Hang Thu Ta and Mingqian Tan Received: 29 April 2019; Accepted: 15 May 2019; Published: 18 June 2019

\begin{abstract}
Since the accumulation of mercury (II) ions in the environment and ecosystem causes serious problems to environment and disease, the recognition of $\mathrm{Hg}^{2+}$ ions and its bio-imaging is of high importance. In sight of the advantages of fluorescence probes, a new probe (PMH) was facilely synthesized by incorporating phenylimidazole fluorophore and 3-methyl-2- benzothiazolinone hydrazone hydrochloride monohydrate. The PMH probe exhibited a ratiometric response for $\mathrm{Hg}^{2+}$ ions with fluorescence intensity increasing at $520 \mathrm{~nm}$ and decreasing at $445 \mathrm{~nm}$ simultaneously. The PMH probe interacted with $\mathrm{Hg}^{2+}$ ions in seconds with high optical stability and showed good selectivity over other metal ions. In addition, the probe has excellent biocompatibility and imaging performance in cells and zebrafish.
\end{abstract}

Keywords: fluorescent probe; $\mathrm{Hg}^{2+}$ ions; phenylimidazole

\section{Introduction}

Mercury is one of the most toxic elements widely existing in water and soil which brings serious threat to the environment and health along with the excessive utilizations in industry and agriculture [1-6]. The toxicity of $\mathrm{Hg}^{2+}$ ions is persistent, refractory, highly biodegradable, which is mainly attributed to the absorption by plants and the transmission through food chains. Mercury (II) ions $\left(\mathrm{Hg}^{2+}\right.$ ions) in water are concentrated in aquatic organisms and then enriched into the human body, which leads to the dysfunction of cells and damages the central nervous and endocrine systems, consequently giving rise to a series of diseases, including acrodynia disease, Alzheimer's disease, Hunter-Russell syndrome disease etc. [7-10]. The tolerable content of inorganic mercury in drinking water is limited according to the World Health Organizations requires. Consequently, rapid and selective recognition of $\mathrm{Hg}^{2+}$ ions in vitro and in vivo is essential [11-15].

To date, $\mathrm{Hg}^{2+}$ ions could be monitored by several testing technologies such as electrochemical analysis, laser ablations inductively coupled plasma mass spectrometry, atomic absorptions spectrometry, voltammetry, UV-vis spectrometry, and atomic emission spectrometry, etc. [16-18]. Compared with these analytical methods, fluorescent techniques have been a promising bio-imaging technique in fields of life sciences, environmental monitoring, and disease diagnosis for their excellent performance targeting metal ions with low cost, good biocompatibility, high sensitivity, selectivity and real-time imaging. Some fluorescent probes have been designed for recognition of $\mathrm{Hg}^{2+}$ ions in recent years [19-25], most of which utilize general fluorophores as signal-output groups such as BODIPY, 1,8-napthalimide, cyanine, coumarin, fluorescein, pyrene, anthracene, and rhodamine etc. [26]. Among a variety of fluorophores, phenylimidazole fluorophore is one of the most famous dyes with a rigid large planar structure and the structure can be flexibly modified. In addition, phenylimidazole has high quantum yield and stable fluorescence and thermodynamic properties 
under photo-oxidation conditions so that it has a wide application in photochemistry and some probes based on phenylimidazole have been developed [27-31]. Moreover, most of these probes response to $\mathrm{Hg}^{2+}$ ions through single emissions intensity change by fluorescence quenching or enhancement, which is likely to be limited to temperature, solvent polarity, medium characteristics, excitations power, dye concentrations, and other factors. Ratiometric fluorescent probes [32-41] perform through the change of fluorescence intensity at two different emission wavelengths simultaneously. The change of the two emission intensity can efficiently cancel out the interferences of the self-fluorescence and the background fluorescence of the detection system.

Herein, a novel ratiometric fluorescence probe PMH (((Z)-2-((E)-(4-(1H-phenanthro [9,10-d] Imidazol-2-yl) benzylidene) hydrazono)-3-methyl-2,3-dihydrobenzo [d] thiazole)) for the recognition of $\mathrm{Hg}^{2+}$ ions was designed and synthesized based on Schiff base reaction between phenylimidazole fluorophore and 3-methyl-2-benzothiazolinone hydrazone (Scheme 1). The PMH probe exhibited a remarkable ratiometric fluorescence response upon the addition of $\mathrm{Hg}^{2+}$ ions. The recognition capability of PMH to $\mathrm{Hg}^{2+}$ ions showed rapid response and excellent stability, which was beneficial to real-time detection. In addition, the PMH probe has excellent selectivity towards $\mathrm{Hg}^{2+}$ over other metal ions. More importantly, the probe has the potential application in imaging of $\mathrm{Hg}^{2+}$ ions in cells and zebrafish.

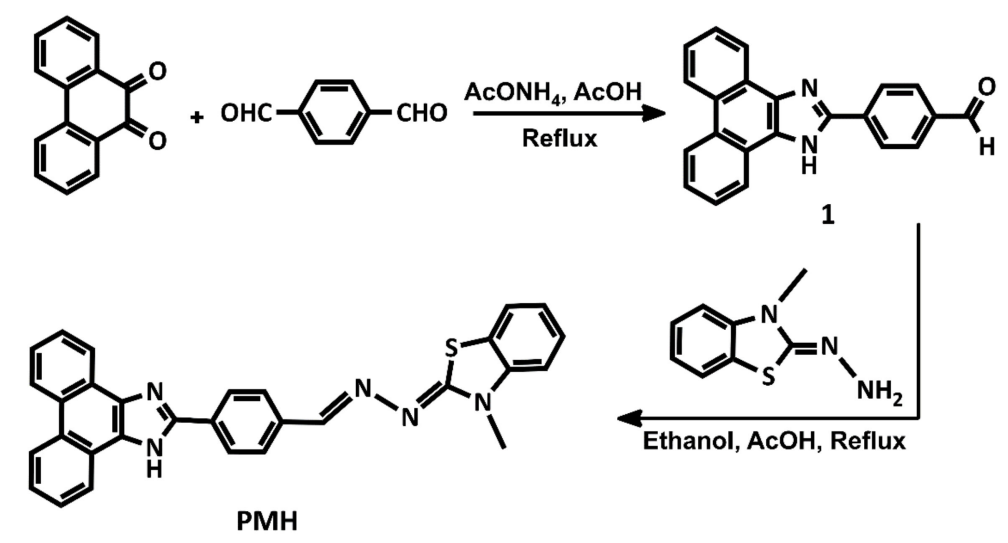

Scheme 1. Synthesis procedure of PMH.

\section{Results}

\subsection{Design Strategy of the PMH Probe}

The PMH probe was designed and synthesized in two steps from phenanthrene quinone moiety, which is an important natural product on account of excellent photo-physical properties. Synthesized from phenanthrene quinone, the phenylimidazole moieties have a high fluorescence quantum yield and large stokes shift which is an excellent fluorophore to compose fluorescent probe. Phenylimidazole fluorophore and 3-methyl-2-benzothiazolinone hydrazine were linked together based on Schiff base reaction. The structure of PMH was confirmed by ${ }^{1} \mathrm{H}$ NMR and ESI-MS. The spectra along could be found in the Supplementary Materials (Figure S1, Figure S2, Figure S3 and Figure S4).

\subsection{Spectral Titration of $\mathbf{P M H}$ with $\mathrm{Hg}^{2+}$ Ions}

The spectroscopic properties of PMH to $\mathrm{Hg}^{2+}$ ions were explored by recording the changes of emission spectra in acetonitrile/water $\left(8: 2, v / v, 0.1 \mathrm{M} \mathrm{KNO}_{3}, \mathrm{pH}=7.34\right)$ solution. The fluorescence titration of PMH in the absence and presence of different amounts of $\mathrm{Hg}^{2+}$ ions (0-15 equiv. to PMH) was shown in Figure 1. Free PMH probe displayed a strong fluorescence emission at $445 \mathrm{~nm}$ when excited at $380 \mathrm{~nm}$. After the addition of $\mathrm{Hg}^{2+}$ ions, the intensity of the emission peak at $445 \mathrm{~nm}$ progressively decreased, and was concomitant with the formation of a new peak around $520 \mathrm{~nm}$. Upon gradual addition of $\mathrm{Hg}^{2+}$ ions, the emission intensity at $520 \mathrm{~nm}$ increased obviously and tended to be 
the dominating emission with the addition of mercury (II) ions. The titration curve reached a plateau on the addition of 15 equivalent $\mathrm{Hg}^{2+}$ ions. The ratiometric response of the emission peaks before and after treatment with $\mathrm{Hg}^{2+}$ ions effectively avoided the emission spectra overlap and the interference of background fluorescence so that it ensured accuracy and high resolution in monitoring of $\mathrm{Hg}^{2+}$ ions.

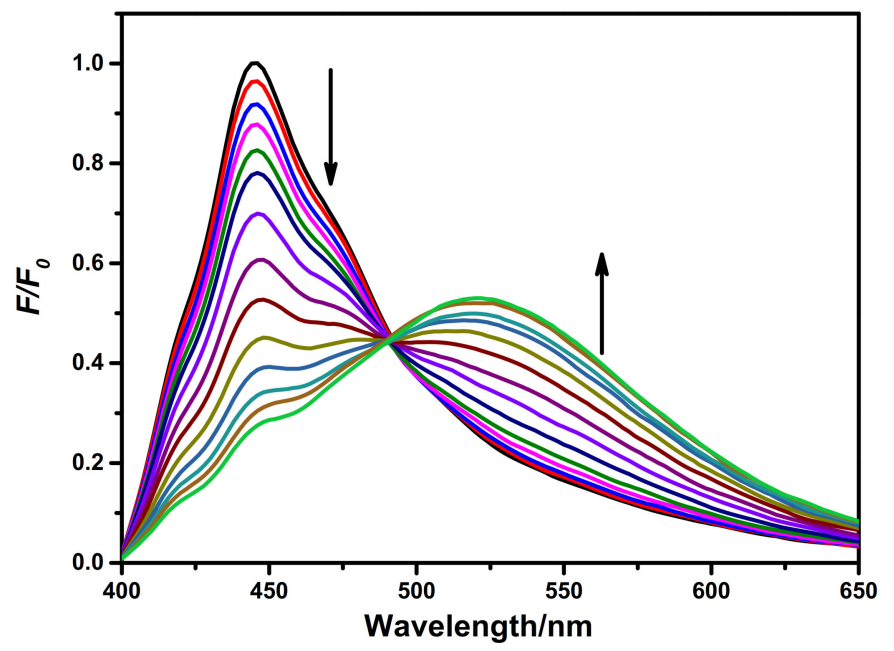

Figure 1. Fluorescence spectra (excited at $380 \mathrm{~nm})$ of PMH $(20 \mu \mathrm{M})$ in the presence of various concentration of $\mathrm{Hg}^{2+}$ ions (0-15 equiv.to PMH) in acetonitrile/water $\left(8: 2, v / v, 0.1 \mathrm{M} \mathrm{KNO}_{3}, \mathrm{pH}=7.34\right)$.

\subsection{Selectivity and Interference Studies}

The selectivity is an important parameter to consider the merits of the probe. To evaluate the selectivity, the fluorescence response of the PMH probe for other metal ions was investigated under the solution of acetonitrile/water $\left(8: 2, v / v, 0.1 \mathrm{M} \mathrm{KNO}_{3}, \mathrm{pH}=7.34\right)$. As shown in Figure $2 \mathrm{a}$, the addition of other metal ions could not lead to apparent changes of the emission at the wavelength at 445 and $520 \mathrm{~nm}$. In contrast, the addition of $\mathrm{Hg}^{2+}$ ions significantly changed the original emission peak mode of the PMH probe, which led to obvious quenching at emission of $445 \mathrm{~nm}$ and enhancement at the $520 \mathrm{~nm}$. Meanwhile, the fluorescence intensity ratio $\mathrm{I}_{520} / \mathrm{I}_{445}$ would not be influenced by other metal ions (wine bars of Figure 2b). As expected, the ratiometric fluorescent response of PMH was highly specific toward mercury ions, and no significant change in fluorescent intensity ratio $\left(\mathrm{I}_{520} / \mathrm{I}_{445}\right)$ was obtained when the probe was treated with other metal cations. When mercury ions were added to the complex of metal ions and PMH respectively, the ratio of fluorescence intensity at $520 \mathrm{~nm}$ and $445 \mathrm{~nm}\left(\mathrm{I}_{520} / \mathrm{I}_{445}\right)$ increased instantaneously, indicating that the recognition of $\mathrm{Hg}^{2+}$ ions could not be interfered by other metal ions (deongaree bars of Figure 2b). The results show that the PMH probe has high selectivity towards $\mathrm{Hg}^{2+}$ ions. 
(a)

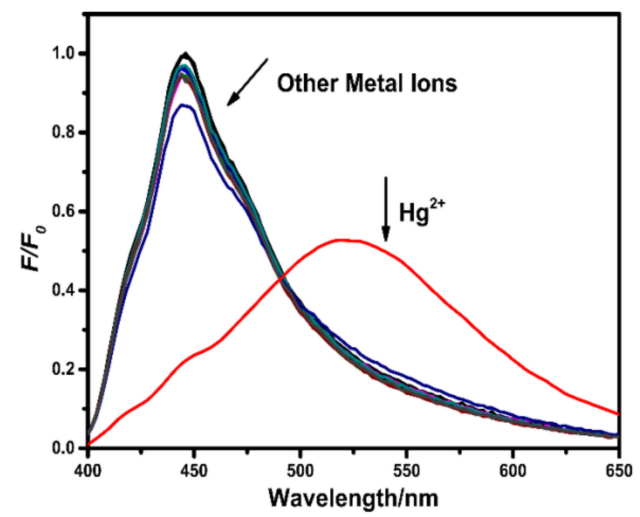

(b)

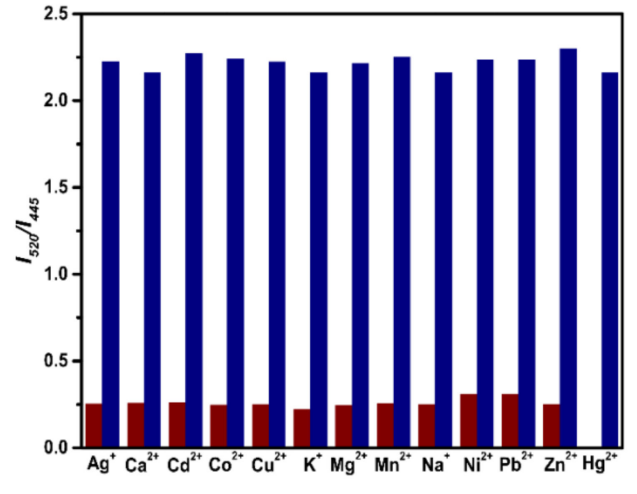

Figure 2. (a) Fluorescence response of the PMH probe $(20 \mu \mathrm{M})$ with the addition of various cations (15 equiv. to PMH). (b) The emission intensity ratio $\left(\mathrm{I}_{520} / \mathrm{I}_{445}\right)$ of $\mathbf{P M H}(20 \mu \mathrm{M})$ to various cations in acetonitrile/water $\left(8: 2, \mathrm{v} / \mathrm{v}, 0.1 \mathrm{M} \mathrm{KNO}_{3}, \mathrm{pH}=7.34\right)$ excited at $380 \mathrm{~nm}$. The wine bars in each group represent the emission intensity ratio $\left(\mathrm{I}_{520} / \mathrm{I}_{445}\right)$ of the $\mathbf{P M H}$ probe in the presence of 15 equiv. of other cations of interest $\left(\mathrm{Hg}^{2+}, \mathrm{Ag}^{+}, \mathrm{Ca}^{2+}, \mathrm{Cd}^{2+}, \mathrm{Co}^{2+}, \mathrm{Cu}^{2+}, \mathrm{K}^{+}, \mathrm{Mg}^{2+}, \mathrm{Mn}^{2+}, \mathrm{Na}^{+}, \mathrm{Ni}^{2+}, \mathrm{Pb}^{2+}, \mathrm{Zn}^{2+}\right)$. The deongaree bars in each group represent the ratio change that occurred upon subsequent addition of 15 equiv. of $\mathrm{Hg}^{2+}$ ions into the above solution.

\subsection{Stability and Time Response}

Stability and response time are important criteria for designing new fluorescence probes. The time-dependent fluorescence experiments were designed and performed. First, the free PMH probe was added into solution of acetonitrile/water $\left(8: 2, v / v, 0.1 \mathrm{M} \mathrm{KNO}_{3}, \mathrm{pH}=7.34\right)$ and the fluorescence signal of PMH was apparently stable within $20 \mathrm{~min}$ (shown in Figure 3). Then, upon the additions of 15 equivalent $\mathrm{Hg}^{2+}$ ions to the probe, the fluorescence emission intensity ratio $\left(\mathrm{I}_{520} / \mathrm{I}_{445}\right)$ increased instantaneously and reached the maximum within seconds, the fluorescence signal maintain stable within $20 \mathrm{~min}$ as well. All these phenomena indicated that the fluorescence of PMH in the absence and presence of $\mathrm{Hg}^{2+}$ ions could remain stable for a period of time. The good stability and rapid response to mercury ions of the probe $\mathbf{P M H}$ is particularly important for the practical real-time detection.

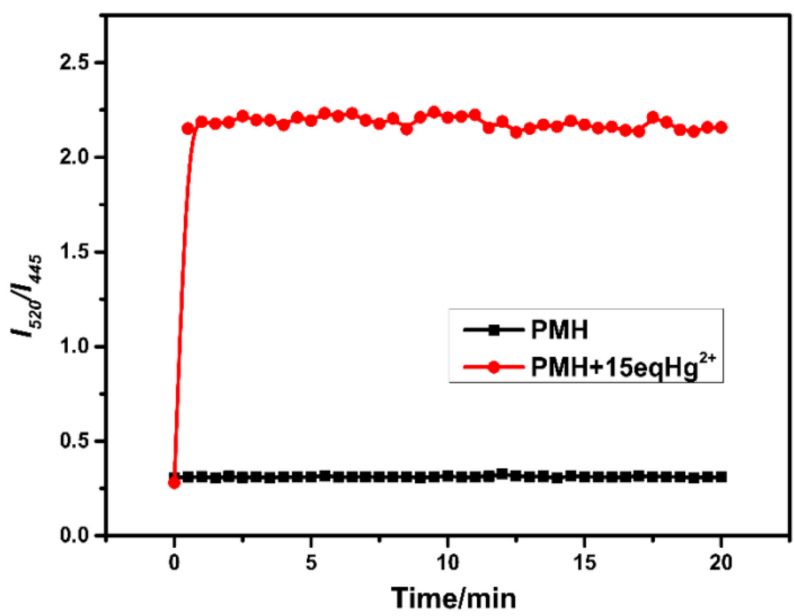

Figure 3. Time-dependent fluorescence intensity ratio $\left(\mathrm{I}_{520} / \mathrm{I}_{445}\right)$ of the $\mathbf{P M H}$ probe (black line) and PMH with the addition 15 equiv. of $\mathrm{Hg}^{2+}$ ions (red line) in solutions of acetonitrile/water $(8: 2, v / v$, $\left.0.1 \mathrm{M} \mathrm{KNO}_{3}, \mathrm{pH}=7.34\right)\left(\lambda_{\text {ex }}=380 \mathrm{~nm}\right)$. 


\subsection{Fluorescence Imaging in Living Cells}

To test the feasibility of the PMH probe for sensing cellular $\mathrm{Hg}^{2+}$ ions, ratiometric fluorescence imaging of MCF-7, A549, Hela cells by confocal microscope were carried out and the images were presented in Figure 4, Figure S6, and Figure S7. First, MCF-7 cells were incubated with PMH (1 $\mu$ M) and then subjected to confocal laser scanning microscopy. As shown in Figure 4, MCF-7 cells exhibited bright fluorescence in the green channel, but low intracellular fluoresence in the red channel. Upon addition of different concentration of $\mathrm{Hg}^{2+}$ ions $(0,5,10,15 \mu \mathrm{M})$ to the PMH-stained cells, fluorescence intensity in the red channel increased dramatically, while the fluorescence in the green channel decreased markedly. Meanwhile, A549 cells and Hela cells were treated with PMH $(1 \mu \mathrm{M})$ and different concentration of $\mathrm{Hg}^{2+}$ ions $(0,5,10,15 \mu \mathrm{M})$ respectively. The images were observed under confocal fluorescence microscope and presented in Figure S5 and Figure S6. Similarly, cells only treated with PMH exhibited bright fluorescence in the green channel and weak fluorescence in the red channel. Upon addition of $\mathrm{Hg}^{2+}$ ions to the PMH-stained cells, fluorescence increased dramatically in the red channel and decreased markedly in the green channel. These results demonstrated that the probe was cell-permeable and suitable for imaging $\mathrm{Hg}^{2+}$ ions in different cells lines.

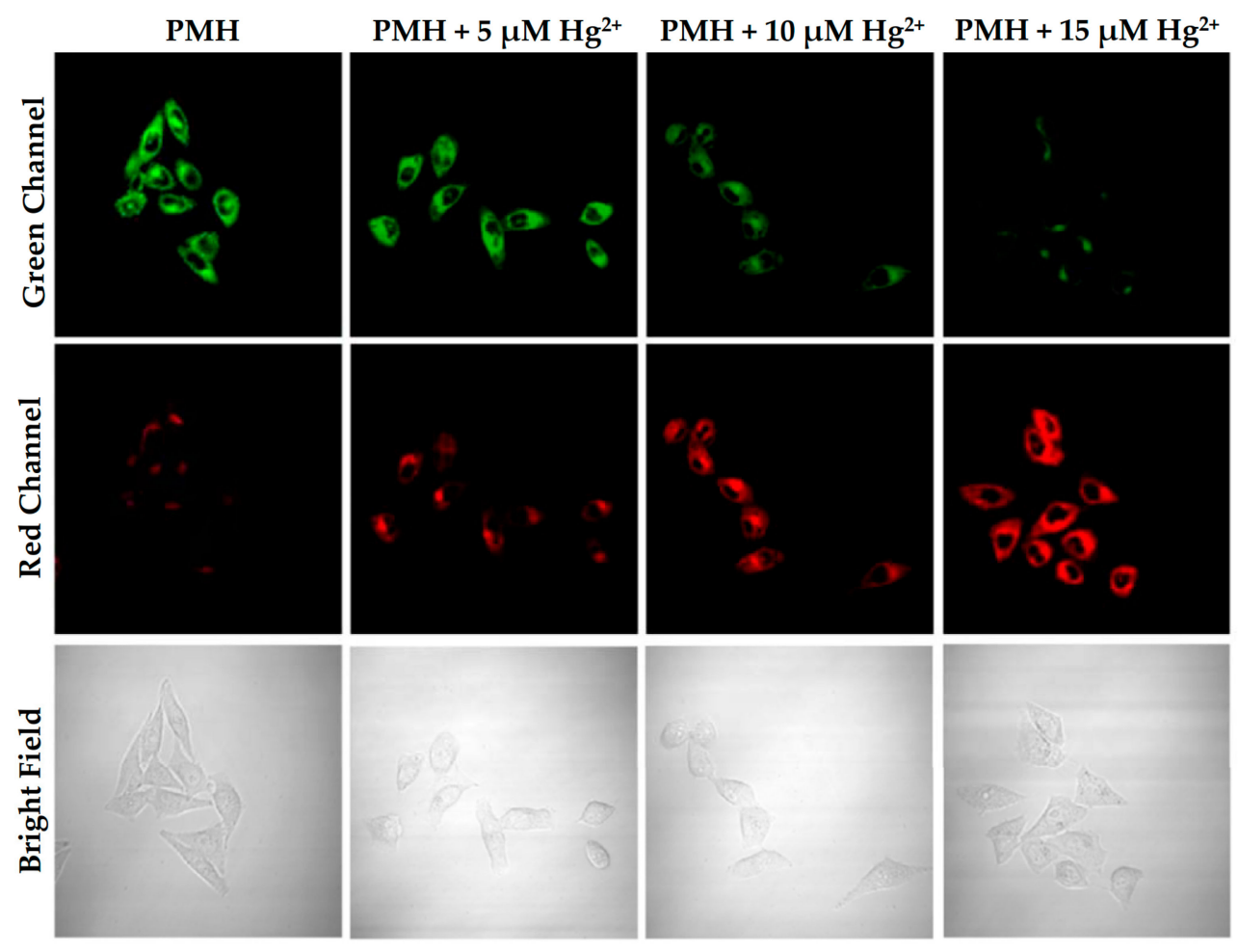

Figure 4. Confocal microscopy images of MCF-7 cells with PMH and $\mathrm{Hg}^{2+}$ ions (excited at $405 \mathrm{~nm})$.treated with PMH $(1 \mu \mathrm{M})$ and $\mathrm{Hg}^{2+}$ ions $(0 \mu \mathrm{M}, 5 \mu \mathrm{M}, 10 \mu \mathrm{M}, 15 \mu \mathrm{M})$ Green Chanel: fluorescent image of emission between $430-460 \mathrm{~nm}$; Red Channel: fluorescent image of emission between $490-550 \mathrm{~nm}$.

\subsection{Zebrafish Imaging}

Zebrafish is known as an excellent vertebrate model organism which is widely used in biology. In view of the advantage of rapid development and transparency of the embryos of zebrafish, the visualization of recognition substance and the potential application can be researched by fluorescence imaging. As shown in Figure 5, zebrafish incubated with PMH showed obvious fluorescence in the green channel and weak fluorescence in the red channel, indicating that the probe could be easily absorbed and distributed throughout the whole organism. As the concentration of $\mathrm{Hg}^{2+}$ ions increased from 0 to $15 \mu \mathrm{M}$, the fluorescence of the green channel gradually decreased while the fluorescence of 
the red channel enhanced markedly, exhibiting that PMH had excellent imaging feasibility in zebrafish. The results imply that the probe has excellent penetration and is suitable for rapid visualization $\mathrm{Hg}^{2+}$ ions zebrafish.

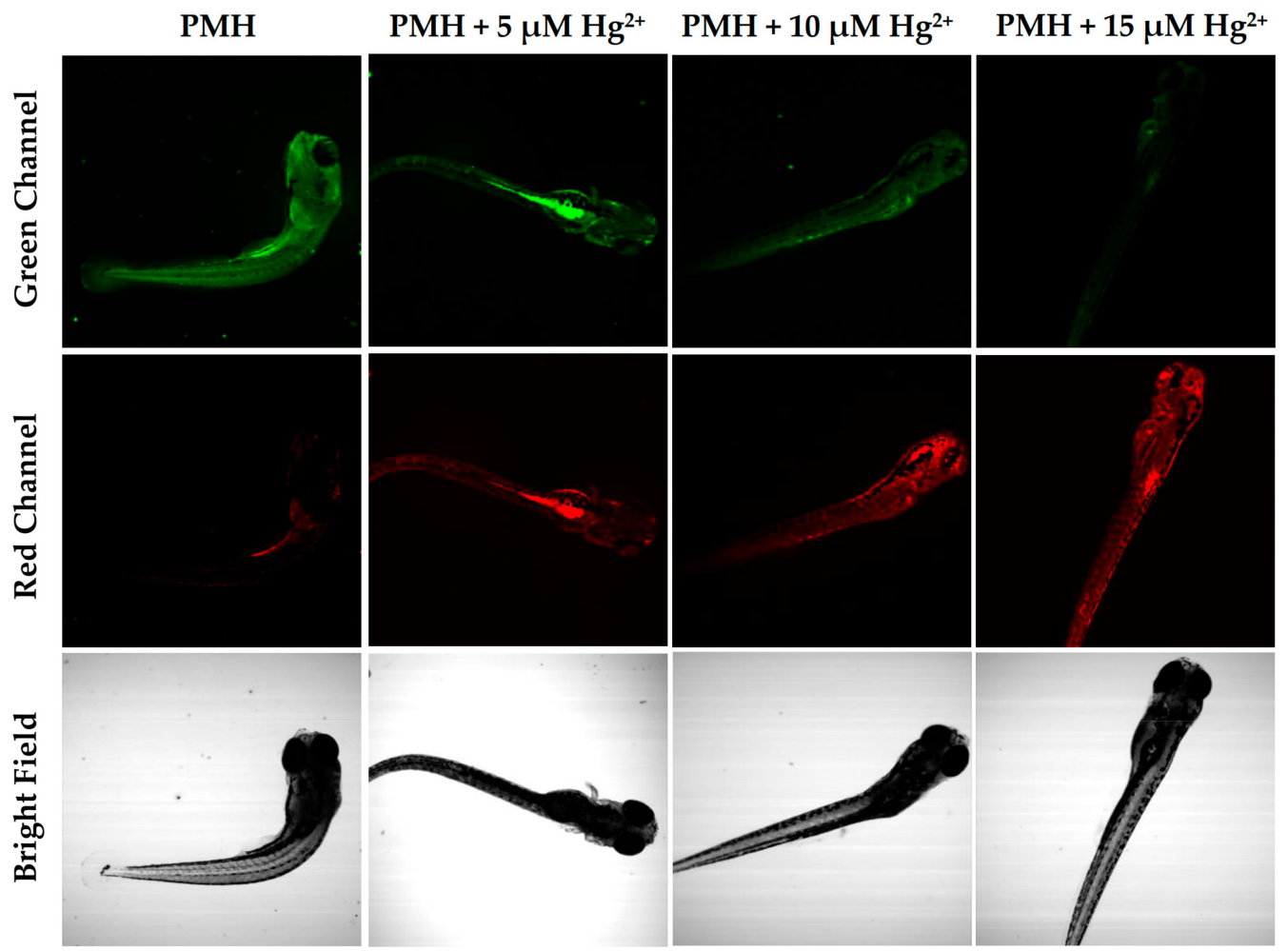

Figure 5. Confocal microscopy images of zebrafish embryos with $\mathbf{P M H}$ and $\mathrm{Hg}^{2+}$ ions. Zebrafish was incubated with the PMH probe $(1 \mu \mathrm{M})$ and followed by different concentration of $\mathrm{Hg}^{2+}$ ions $(0 \mu \mathrm{M}$, $5 \mu \mathrm{M}, 10 \mu \mathrm{M}, 15 \mu \mathrm{M}) . \lambda_{\mathrm{ex}}=405 \mathrm{~nm}$, Green Channel: fluorescent image of emission between 430-460 nm; Red Chanel: fluorescent image of emission between 490-550 nm.

\section{Experimental}

\subsection{Materials and General Method}

9,10-phenanthroquinone, terephthalaldehyde, $\mathrm{KNO}_{3}$ were purchased from Energy Chemical (Shanghai, China). 3-methyl-2-benzothiazolinone hydrazone hydrochloride monohydrate and the salts of metal ions $\left(\mathrm{NaClO}_{4} \cdot \mathrm{H}_{2} \mathrm{O}, \mathrm{Fe}\left(\mathrm{ClO}_{4}\right)_{2} \cdot 6 \mathrm{H}_{2} \mathrm{O}, \mathrm{Zn}\left(\mathrm{ClO}_{4}\right)_{2} \cdot 6 \mathrm{H}_{2} \mathrm{O}, \mathrm{Cu}\left(\mathrm{ClO}_{4}\right)_{2} \cdot 6 \mathrm{H}_{2} \mathrm{O}\right.$, $\mathrm{KClO}_{4}, \mathrm{Ca}\left(\mathrm{ClO}_{4}\right)_{2} \cdot 4 \mathrm{H}_{2} \mathrm{O}, \mathrm{Mg}\left(\mathrm{ClO}_{4}\right)_{2} \cdot 6 \mathrm{H}_{2} \mathrm{O}, \mathrm{AgClO}{ }_{4} \cdot 6 \mathrm{H}_{2} \mathrm{O}, \mathrm{Mn}\left(\mathrm{ClO}_{4}\right)_{2} \cdot 6 \mathrm{H}_{2} \mathrm{O}, \mathrm{Cd}\left(\mathrm{ClO}_{4}\right)_{2} \cdot 6 \mathrm{H}_{2} \mathrm{O}$, $\left.\mathrm{Co}\left(\mathrm{ClO}_{4}\right)_{2} \cdot 6 \mathrm{H}_{2} \mathrm{O}, \mathrm{Ni}\left(\mathrm{ClO}_{4}\right)_{2} \cdot 6 \mathrm{H}_{2} \mathrm{O}, \mathrm{Pd}\left(\mathrm{ClO}_{4}\right)_{2} \cdot 6 \mathrm{H}_{2} \mathrm{O}, \mathrm{Hg}\left(\mathrm{ClO}_{4}\right)_{2} \cdot 3 \mathrm{H}_{2} \mathrm{O}\right)$ were purchased from $\mathrm{J} \& \mathrm{~K}$ Scientific (Shanghai, China). Solvents such as glacial acetic acid, methanol, ethanol, acetonitrile are commercially available analytical grades and were used directly. Experimental water was deionized water. ${ }^{1} \mathrm{H}$ NMR spectra were measured on a Bruker AVANCE III 500 (Bruker, Bremen, Germany) at room temperature. Mass spectra were carried out on a LTQ Orbitrap XL spectrometer (Thermo Scientific, MA, USA) using methanol as mobile phase. The reactions were monitored by TLC and were visualized by UV lamp (254 $\mathrm{nm}$ and $365 \mathrm{~nm}$ ). The fluorescent spectra were measured on EDINBURGH FS920 (Edinburgh Instruments, UK), $\Delta \lambda=1.1 \mathrm{~nm}$ with the excitations at $380 \mathrm{~nm}$. Fluorescence images of cells were recorded by an Olympus FV1000 confocal microscope (Olympus, Kyoto, Japan).

\subsection{Synthesis of Compound 1 (4-(1H-phenanthro[9,10-d]imidazol-2-yl)benzaldehyde)}

A mixture of 9,10-phenanthroquinone (208 mg, $1 \mathrm{mmol})$, ammonium acetate (153.9 $\mathrm{mg}, 2 \mathrm{mmol})$, and terephthalaldehyde $(135.2 \mathrm{mg}, 1 \mathrm{mmol})$ were stirred in glacial $\mathrm{AcOH}(15 \mathrm{~mL})$ under reflux 
conditions for $30 \mathrm{~min}$ [42]. The hot solution was cooled to room temperature, and the resulting yellow solid was collected by filtrations and washed with an excess amount of water and methanol to remove starting materials. Yield: $260 \mathrm{mg}, 79.43 \% .{ }^{1} \mathrm{H}$ NMR $\left(500 \mathrm{MHz}, \mathrm{DMSO}-d_{6}\right) \delta 13.66(\mathrm{~s}, 1 \mathrm{H}), 10.05(\mathrm{~s}, 1 \mathrm{H})$, $8.81(\mathrm{~m}, 2 \mathrm{H}), 8.62(\mathrm{~d}, 1 \mathrm{H}), 8.56(\mathrm{~d}, 1 \mathrm{H}), 8.50(\mathrm{~d}, 2 \mathrm{H}), 8.08(\mathrm{~d}, 2 \mathrm{H}), 7.74(\mathrm{~m}, 2 \mathrm{H}), 7.63(\mathrm{~m}, 2 \mathrm{H})$. ESI-MS: $m / z=323.1176$ for $[\mathrm{M}+\mathrm{H}]^{+}$.

\subsection{Synthesis of PMH (((Z)-2-((E)-(4-(1H-phenanthro[9,10-d]imidazol-2-yl) benzylidene) hydrazono)-3-methyl-2,3-dihydrobenzo[d]thiazole))}

Compound 1 (322 mg, $1 \mathrm{mmol}$ ) was dissolved in $20 \mathrm{~mL}$ of hot absolute ethanol, then 3-methyl-2-benzothiazolinone hydrazone hydrochloride monohydrate $(233 \mathrm{mg}, 1 \mathrm{mmol})$ was added to the solution. The mixture was stirred under reflux conditions for $4 \mathrm{~h}$ to attain the product [43]. The yellow precipitate was filtrated and washed with hot absolute ethanol for three times and dried in vacuum to give compound PMH. Yield: $432 \mathrm{mg}, 78.21 \% .{ }^{1} \mathrm{H}$ NMR (500 MHz, DMSO- $\left.d_{6}\right) \delta 13.76(\mathrm{br}$, $1 \mathrm{H}), 8.87(\mathrm{t}, 2 \mathrm{H}), 8.69(\mathrm{~m}, 2 \mathrm{H}), 8.62(\mathrm{~s}, 1 \mathrm{H}), 8.48(\mathrm{~d}, 2 \mathrm{H}), 7.97(\mathrm{~d}, 1 \mathrm{H}), 7.75(\mathrm{~m}, 3 \mathrm{H}), 7.67(\mathrm{~m}, 3 \mathrm{H}), 7.34(\mathrm{~m}$, 2H), $7.13(\mathrm{t}, 1 \mathrm{H}), 3.61(\mathrm{~s}, 3 \mathrm{H})$. ESI-MS: $m / z=484.1580$ for $[\mathrm{M}+\mathrm{H}]^{+}$.

\subsection{Spectrophotometric Experiments}

The salts of metal ions were dissolved in distilled water to afford $1.0 \times 10^{-2} \mathrm{M}$ mother liquors. PMH was dissolved in dimethyl sulfoxide to prepare a solution with the concentrations of $1.0 \times 10^{-3} \mathrm{M}$. Aliquots of stock solutions of PMH were diluted to $2 \mathrm{~mL}$ acetonitrile/water $\left(8: 2, v / v, 0.1 \mathrm{M} \mathrm{KNO}_{3}\right.$, $\mathrm{pH}=7.34)$ to make the final concentrations of $20 \mu \mathrm{M}$. The selective assay of PMH $(20 \mu \mathrm{M})$ was researched in the presence of various competitive species under the same condition were recorded by $\mathrm{I}_{520} / \mathrm{I}_{445}$ excited at $380 \mathrm{~nm}$.

\subsection{Cell Culture and Imaging}

MCF-7, Hela cell lines were cultured in Dulbecco's modified Eagle's medium (DMEM) and A549 cells were cultured in RPMI-1640 including $10 \%$ fetal bovine serum at $37^{\circ} \mathrm{C}$ in an incubator containing $5 \% \mathrm{CO}_{2}$ respectively. For imaging of $\mathrm{Hg}^{2+}$ in living cells, the cells were treated with $1 \mu \mathrm{M}$ of $\mathbf{P M H}$ under the growth medium and then incubated with varied concentrations of $\mathrm{Hg}^{2+}$ ions $(0,5,10,15 \mu \mathrm{M})$. The cells were washed by PBS three times and then cell images were obtained via a confocal microscope from Olympus FV1000 laser confocal microscope at excitations of $405 \mathrm{~nm}$. The green channel collected the emission wavelength between 430-460 $\mathrm{nm}$ and the red channel collected the emission wavelength between 490-550 $\mathrm{nm}$.

\subsection{Zebrafish Imaging}

Zebrafish embryos were maintained at $28^{\circ} \mathrm{C}$ and washed with $\mathrm{E} 3$ for fluorescence imaging. For ratiometric imaging, the green channel collected the emission wavelength between $430-460 \mathrm{~nm}$ and the red channel collected the emission wavelength between 490-550 nm. Confocal fluorescence images were recorded on an Olympus FV1000 laser confocal microscope at excitation of $405 \mathrm{~nm}$.

\section{Conclusions}

In conclusion, a novel phenylimidazole-based ratiometric fluorescent probe PMH has been developed and synthesized by Schiff base reaction. PMH probe could recognize $\mathrm{Hg}^{2+}$ rapidly and present excellent stability. The addition of $\mathrm{Hg}^{2+}$ ions to $\mathbf{P M H}$ results in a ratiometric fluorescence response with a dramatic enhancement of fluorescence intensity at $520 \mathrm{~nm}$ and a significant decrease at $445 \mathrm{~nm}$. PMH shows high selectivity toward $\mathrm{Hg}^{2+}$ ions over other metal ions. Remarkably, the probe has excellent biocompatible and successful utilization in bio-imaging in cells and zebrafish.

Supplementary Materials: Supplementary data associated with this article can be found in the online. 
Author Contributions: Conceptualization and methodology, Y.J.; formal analysis, preparation and writing—original draft, Q.G.; writing—review and editing, Q.G. and Y.J.; project administration, C.H.; supervision and funding acquisition, C.D.

Funding: This work was supported by the NSFC (Nos. 21820102001 and 21501020).

Conflicts of Interest: The authors declare no conflict of interest.

\section{References}

1. Tan, S.W.; Meiller, J.C.; Mahaffey, K.R. The endocrine effects of mercury in humans and wildlife. Crit. Rev. Toxicol. 2009, 39, 228-269. [CrossRef] [PubMed]

2. Carter, K.P.; Young, A.M.; Palmer, A.E. Fluorescent sensors for measuring metal ions in living systems. Chem. Rev. 2014, 114, 4564-4601. [CrossRef] [PubMed]

3. Ding, S.-Y.; Dong, M.; Wang, Y.-W.; Chen, Y.-T.; Wang, H.-Z.; Su, C.-Y.; Wang, W. Thioether-based fluorescent covalent organic framework for selective detection and facile removal of mercury (II). J. Am. Chem. Soc. 2016, 138, 3031-3037. [CrossRef] [PubMed]

4. Nolan, E.M.; Lippard, S.J. Tools and tactics for the optical detection of mercuric ion. Chem. Rev. 2008, 108, 3443-3480. [CrossRef] [PubMed]

5. Renzoni, A.; Zino, F.; Franchi, E. Mercury levels along the food chain and risk for exposed populations. Environ. Res. 1998, 77, 68-72. [CrossRef] [PubMed]

6. Malm, O. Gold mining as a source of mercury exposure in the Brazilian Amazon. Environ. Res. 1998, 77, 73-78. [CrossRef]

7. Bolger, P.M.; Schwetz, B. Mercury and health. New Engl. J. Med. 2002, 347, 1735-1736. [CrossRef] [PubMed]

8. Taki, M.; Akaoka, K.; Iyoshi, S.; Yamamoto, Y. Rosamine-based fluorescent sensor with femtomolar affinity for the reversible detection of a mercury ion. Inorg. Chem. 2012, 51, 13075-13077. [CrossRef] [PubMed]

9. Ma, S.; Li, L.; She, M.; Mo, Y.; Zhang, S.; Liu, P.; Li, J. Synthesis and application of highly sensitive fluorescent probe for $\mathrm{Hg}^{2+}$ regulated by sulfur. Chin. Chem. Lett. 2017, 28, 2014-2018. [CrossRef]

10. Li, X.-M.; Zhao, R.-R.; Wei, Y.-L.; Yang, D.; Zhou, Z.-J.; Zhang, J.-F.; Zhou, Y. A rhodamine derivative for $\mathrm{Hg}^{2+}$-selective colorimetric and fluorescent sensing and its application to in vivo imaging. Chin. Chem. Lett. 2016, 27, 813-816. [CrossRef]

11. Park, J.-D.; Zheng, W. Human exposure and health effects of inorganic and elemental mercury. J. Prev. Med. Public Health 2012, 45, 344. [CrossRef]

12. Wang, S.; Shi, X. Molecular mechanisms of metal toxicity and carcinogenesis. Mol. Cell. Biochem. 2001, 222, 3-9. [CrossRef] [PubMed]

13. Tchounwou, P.B.; Yedjou, C.G.; Patlolla, A.K.; Sutton, D.J. Heavy metal toxicity and the environment. In Molecular, Clinical and Environmental Toxicology; Springer: Basel, Switzerland, 2012; pp. 133-164.

14. Chen, X.; Meng, X.; Wang, S.; Cai, Y.; Wu, Y.; Feng, Y.; Zhu, M.; Guo, Q. A rhodamine-based fluorescent probe for detecting $\mathrm{Hg}^{2+}$ in a fully aqueous environment. Dalton Trans. 2013, 42, 14819-14825. [CrossRef]

15. Jiao, Y.; Zhang, L.; Zhou, P. A rhodamine B-based fluorescent sensor toward highly selective mercury (II) ions detection. Talanta 2016, 150, 14-19. [CrossRef]

16. Bernaus, A.; Gaona, X.; Esbrí, J.M.; Higueras, P.; Falkenberg, G.; Valiente, M. Microprobe techniques for speciation analysis and geochemical characterization of mine environments: The mercury district of Almadén in Spain. Environ. Sci. Technol. 2006, 40, 4090-4095. [CrossRef] [PubMed]

17. Wang, L.; Zhou, J.-B.; Wang, X.; Wang, Z.-H.; Zhao, R.-S. Simultaneous determination of copper, cobalt, and mercury ions in water samples by solid-phase extraction using carbon nanotube sponges as adsorbent after chelating with sodium diethyldithiocarbamate prior to high performance liquid chromatography. Anal. Bioanal. Chem. 2016, 408, 4445-4453. [CrossRef] [PubMed]

18. Abollino, O.; Giacomino, A.; Malandrino, M.; Piscionieri, G.; Mentasti, E. Determination of mercury by anodic stripping voltammetry with a gold nanoparticle-modified glassy carbon electrode. Electroanal. Int. J. Devoted Fundam. Pract. Asp. Electroanal. 2008, 20, 75-83. [CrossRef]

19. Chen, J.; Shu, W.; Wang, E. A fluorescent and colorimetric probe based on isatin-appended rhodamine for the detection of $\mathrm{Hg}^{2+}$. Chem. Res. Chin. Univ. 2016, 32, 742-745. [CrossRef] 
20. Li, L.; Wang, S.; Lan, H.; Gong, G.; Zhu, Y.; Tse, Y.C.; Wong, K.M.C. Rhodol derivatives as selective fluorescent probes for the detection of HgII Ions and the bioimaging of hypochlorous acid. ChemistryOpen 2018, 7, 136-143. [CrossRef] [PubMed]

21. Lu, H.-L.; Wang, W.-K.; Tan, X.-X.; Luo, X.-F.; Zhang, M.-L.; Zhang, M.; Zang, S.-Q. A new quinoline-based fluorescent probe for $\mathrm{Cd}^{2+}$ and $\mathrm{Hg}^{2+}$ with an opposite response in a $100 \%$ aqueous environment and live cell imaging. Dalton Trans. 2016, 45, 8174-8181. [CrossRef]

22. Dong, J.; Hu, J.; Baigude, H.; Zhang, H. A novel ferrocenyl-naphthalimide as a multichannel probe for the detection of $\mathrm{Cu}$ (II) and $\mathrm{Hg}$ (II) in aqueous media and living cells. Dalton Trans. 2018, 47, 314-322. [CrossRef] [PubMed]

23. Liu, H.; Ding, H.; Zhu, L.; Wang, Y.; Chen, Z.; Tian, Z. A indole-trizole-rhodamine triad as ratiometric fluorescent probe for nanomolar-concentration level $\mathrm{Hg}^{2+}$ sensing with high selectivity. J. Fluoresc. 2015, 25, 1259-1266. [CrossRef] [PubMed]

24. Biswal, B.; Mallick, D.; Bag, B. Signaling preferences of substituted pyrrole coupled six-membered rhodamine spirocyclic probes for $\mathrm{Hg}^{2+}$ ion detection. Org. Biomol. Chem. 2016, 14, 2241-2248. [CrossRef] [PubMed]

25. Han, X.; Lü, X.; Chen, Z.; Yu, G.; Yin, J.; Liu, S. A fluorescent probe for $\mathrm{Hg}^{2+}$ based on gold (I) complex with an aggregation-induced emission feature. Chin. J. Chem. 2015, 33, 1064-1068. [CrossRef]

26. Mahato, P.; Saha, S.; Das, P.; Agarwalla, H.; Das, A. An overview of the recent developments on $\mathrm{Hg}^{2+}$ recognition. RSC Adv. 2014, 4, 36140-36174. [CrossRef]

27. Gülle, S.; Erbaş, S.Ç.; Uzel, A. Synthesis and spectroscopic studies of phenanthroimidazole-imine derivatives and evaluation of their antioxidant activity. J. Fluoresc. 2018, 28, 217-223. [CrossRef]

28. Hwang, S.M.; Chae, J.B.; Kim, C. A Phenanthroimidazole-based Fluorescent Turn-Off Chemosensor for the Selective Detection of $\mathrm{Cu}^{2+}$ in Aqueous Media. Bull. Korean Chem. Soc. 2018, 39, 925-930. [CrossRef]

29. Anbu, S.; Shanmugaraju, S.; Ravishankaran, R.; Karande, A.A.; Mukherjee, P.S. A phenanthrene based highly selective fluorogenic and visual sensor for $\mathrm{Cu}^{2+}$ ion with nanomolar detection limit and its application in live cell imaging. Inorg. Chem. Commun. 2012, 25, 26-29. [CrossRef]

30. Sinha, S.; Chowdhury, B.; Ghosh, P. A highly sensitive ESIPT-based ratiometric fluorescence sensor for selective detection of $\mathrm{Al}^{3+}$. Inorg. Chem. 2016, 55, 9212-9220. [CrossRef]

31. Ramu, V.; Roy, S.; Taye, N.; Chattopadhyay, S.; Das, A. A specific probe for $\mathrm{Hg}^{2+}$ to delineate even $\mathrm{H}^{+}$in pure aqueous buffer/Hct116 colon cancer cells: $\mathrm{Hg}$ (ii) $-\eta^{2}$-arene $\pi$-interaction and a TBET-based fluorescence response. Chem. Commun. 2014, 50, 14421-14424.

32. Jiao, X.; Liu, C.; He, S.; Zhao, L.; Zeng, X. Highly selective and sensitive ratiometric near-infrared fluorescent probe for rel-time detection of $\mathrm{Hg}^{2+}$ and its bioapplications in live cells. Dyes Pigments 2019, 160, 86-92. [CrossRef]

33. Fan, J.; Hu, M.; Zhan, P.; Peng, X. Energy transfer cassettes based on organic fluorophores: Construction and applications in ratiometric sensing. Chem. Soc. Rev. 2013, 42, 29-43. [CrossRef] [PubMed]

34. Yuan, L.; Lin, W.; Zheng, K.; Zhu, S. FRET-based small-molecule fluorescent probes: rational design and bioimaging applications. Acc. Chem. Res. 2013, 46, 1462-1473. [CrossRef] [PubMed]

35. Huang, Y.; Li, C.-F.; Shi, W.-J.; Tan, H.-Y.; He, Z.-Z.; Zheng, L.; Liu, F.; Yan, J.-W. A near-infrared BODIPY-based fluorescent probe for ratiometric and discriminative detection of $\mathrm{Hg}^{2+}$ and $\mathrm{Cu}^{2+}$ ions in living cells. Talanta 2019, 198, 390-397. [CrossRef] [PubMed]

36. Chu, K.-H.; Zhou, Y.; Fang, Y.; Wang, L.-H.; Li, J.-Y.; Yao, C. Rhodamine-pyrene conjugated chemosensors for ratiometric detection of $\mathrm{Hg}^{2+}$ ions: Different sensing behavior between a spirolactone and a spirothiolactone. Dye Pigment 2013, 98, 339-346. [CrossRef]

37. Li, J.; Yim, D.; Jang, W.-D.; Yoon, J. Recent progress in the design and applications of fluorescence probes containing crown ethers. Chem. Soc. Rev. 2017, 46, 2437-2458. [CrossRef] [PubMed]

38. Zhou, Y.; He, X.; Chen, H.; Wang, Y.; Xiao, S.; Zhang, N.; Li, D.; Zheng, K. An ESIPT/ICT modulation based ratiometric fluorescent probe for sensitive and selective sensing $\mathrm{Hg}^{2+}$. Sens. Actuat. B Chem. 2017, 247, 626-631. [CrossRef]

39. Chen, X.; Wang, F.; Hyun, J.Y.; Wei, T.; Qiang, J.; Ren, X.; Shin, I.; Yoon, J. Recent progress in the development of fluorescent, luminescent and colorimetric probes for detection of reactive oxygen and nitrogen species. Chem. Soc. Rev. 2016, 45, 2976-3016. [CrossRef] 
40. Hu, B.; Hu, L.-L.; Chen, M.-L.; Wang, J.-H. A FRET ratiometric fluorescence sensing system for mercury detection and intracellular colorimetric imaging in live Hela cells. Biosens. Bioelectron. 2013, 49, 499-505. [CrossRef]

41. Wu, C.; Wang, J.; Shen, J.; Bi, C.; Zhou, H. Coumarin-based $\mathrm{Hg}^{2+}$ fluorescent probe: Synthesis and turn-on fluorescence detection in neat aqueous solution. Sens. Actuat. B Chem. 2017, 243, 678-683. [CrossRef]

42. Lin, W.; Long, L.; Yuan, L.; Cao, Z.; Chen, B.; Tan, W. A ratiometric fluorescent probe for cysteine and homocysteine displaying a large emission shift. Org. Lett. 2008, 10, 5577-5580. [CrossRef] [PubMed]

43. Jiao, Y.; Liu, X.; Zhou, L.; He, H.; Zhou, P.; Duan, C. A schiff-base dual emission ratiometric fluorescent chemosensor for $\mathrm{Hg}^{2+}$ ions and its application in cellular imaging. Sens. Actuat. B Chem. 2017, 247, 950-956. [CrossRef]

Sample Availability: Samples of the compounds PMH are available from the authors.

(C) 2019 by the authors. Licensee MDPI, Basel, Switzerland. This article is an open access article distributed under the terms and conditions of the Creative Commons Attribution (CC BY) license (http://creativecommons.org/licenses/by/4.0/). 